\title{
Characterizing the literature surrounding transportation of young dairy calves: A scoping review
}

\author{
H. M. Goetz, ${ }^{1} \odot$ C. B. Winder, ${ }^{1} \odot$ J. H. C. Costa, ${ }^{2} \odot$ K. C. Creutzinger, ${ }^{1}$ T. Uyama, ${ }^{1} \odot$ D. F. Kelton, ${ }^{1} \odot$ J. Dunn, ${ }^{1} \odot$ \\ and D. L. Renaud ${ }^{1 *}$ (]) \\ ${ }^{1}$ Department of Population Medicine, University of Guelph, Guelph, ON, Canada, N1G 2W1 \\ ${ }^{2}$ Department of Animal and Food Sciences, University of Kentucky, Lexington 40508
}

\begin{abstract}
Transportation is a stressful event for cattle, as it may involve various handling practices, commingling, deprivation of food and water, and fluctuating temperatures. Calves are particularly susceptible to these stressors because their physiological and immune systems are still developing. There has been no formal synthesis of the scientific literature evaluating the effect of transportation on young dairy calf health and performance; the aim of this scoping review is to describe and characterize this body of work. We targeted both descriptive and analytic studies examining transport of calves, including listing how the effect of transport has been evaluated. Eight databases were searched for relevant articles with eligible studies being primary research articles investigating transportation of calves of either sex who were younger than $60 \mathrm{~d}$ of age or weighed less than $100 \mathrm{~kg}$. Two reviewers independently screened the title and abstracts of 6,859 articles with 361 potentially relevant articles screened at full text. Of these, 46 were relevant and had data extracted. Articles reporting study location were conducted in the United States $(\mathrm{n}=5)$, Australia $(\mathrm{n}=3)$, Japan $(\mathrm{n}=3)$, and New Zealand $(\mathrm{n}=3)$. Common transport-related variables evaluated included time in transit $(\mathrm{n}=13)$, distance of transportation ( $\mathrm{n}=8)$, vehicle-related factors $(\mathrm{n}=8)$, and age at time of transportation $(\mathrm{n}=$ 4). Outcome measures varied greatly, including blood parameters $(\mathrm{n}=28)$, health assessments $(\mathrm{n}=20)$, weight $(\mathrm{n}=17)$, behavioral metrics $(\mathrm{n}=14)$, mortality $(\mathrm{n}=7)$, feed intake following transportation $(\mathrm{n}=4)$, salivary cortisol concentrations $(\mathrm{n}=3)$, morbidity $(\mathrm{n}=$ 3 ), and isolation of Salmonella Dublin in fecal samples $(\mathrm{n}=2)$. Outcome parameters were measured during transport or ranged from immediately after to one year following transportation. As the transport-related risk
\end{abstract}

Received August 26, 2021.

Accepted October 15, 2021.

*Corresponding author: renaudd@uoguelph.ca factors and outcomes measured assessed varied widely between studies, future quantitative synthesis (e.g., meta-analysis) in this area may be limited. Several knowledge gaps were identified, including methods to prepare calves for transportation, such as improving nutrition, administering medication, or transporting calves at an older age or weight. Further research could also focus on consistent and clear reporting of key items related to study conduct and analysis, as well as the development of a core outcome set for calf transport studies.

Key words: bull calf, veal industry

\section{INTRODUCTION}

Transportation poses an extreme stress for animals, as they may experience different handling techniques, commingling with unfamiliar animals in new environments, deprivation of food and water, and fluctuating temperatures (Trunkfield and Broom, 1990). This event is physiologically challenging for young calves due to their reduced ability to thermoregulate and the occurrence of dehydration during transport (Schrama et al., 1993; Gebresenbet et al., 2012; Pempek et al., 2017). In the US dairy industry, calves moving to a heifer or calf raiser may require transportation. About 1 in 10 operations in the United States raised some of their dairy heifers off-site, $40 \%$ of which primarily transported the calves off-site at an average age of $6 \mathrm{~d}$ (NAHMS, 2014). In the context of the North American veal and dairybeef industries, most calves must be transported from the source dairy farm to another facility for raising. Regardless of the end destination, transporting calves may lead to a less effective immune system and could contribute to the high risk of morbidity, mortality, and reduced ADG calves experience during the growing period at calf-raising facilities (Mormède et al., 1982).

The effect of transportation has been measured by evaluating behavioral indicators, hematological variables, and physiological changes in calves. Behaviors, such as standing or lying, have been recorded during 
and following transportation as a method to assess calf welfare. Lying time is greater in younger calves during transportation, and recovery from transport and can also be influenced by bedding availability and stocking density (Jongman and Butler, 2014). Haptoglobin and creatine kinase have been documented to increase following transport, suggesting inflammation and muscle damage occurs as a result (Lomborg et al., 2008; Jongman and Butler, 2014; Chibisa et al., 2018). Furthermore, a loss of up to $11 \%$ of BW occurs during transport of cattle before slaughter and suppression of growth for up to $28 \mathrm{~d}$ after transport has been reported in feeder steers (Cole et al., 1988; Warriss, 1990). These short- and long-term effects highlight the impact transportation can have on calf health, welfare, and productivity.

In studies evaluating the impact of transport on young dairy calves, several factors have been examined, including management before transport, loading, transport environment, climatic conditions, duration of transport, as well as animal characteristics (Nielsen et al., 2011). However, providing evidence-based guidelines for transportation of young calves is challenging because the effect of transportation on calves is complex. A narrative review in this area has been published (Roadknight et al., 2021), but to our knowledge there has been no formal synthesis of the literature in this area. To improve the understanding of the breadth and depth of the literature surrounding transportation, a formal synthesis of studies evaluating transportation of calves is necessary. A scoping review is appropriate to qualitatively summarize a range of evidence to convey the breadth and depth of a field, examine the extent and nature of research activity, and identify gaps in the literature (Levac et al., 2010; Arksey and O'Malley, 2005). Synthesizing the literature about the effect of transportation on calves is imperative to make informed decisions that will ultimately improve calf health and welfare.

The objective of this scoping review is to describe and characterize the existing literature examining transport of young calves. This review will describe how transport has been assessed in the literature, what potential risk factors have been examined, and what outcomes have been measured. It will also serve to identify knowledge gaps in the literature.

\section{MATERIALS AND METHODS}

This article is reported following the PRISMA extension for scoping reviews (PRISMA-ScR; Tricco et al., 2018).

\section{Protocol and Registration}

The protocol for this scoping review was developed using the PRISMA extension for scoping reviews (PRISMA-ScR; Tricco et al., 2018). It was established before beginning this study and is available in the University of Guelph Atrium (https://atrium .lib.uoguelph.ca/xmlui/bitstream/handle/10214/ 18061/TransportScopingReviewProtocol_June24.pdf ?sequence $=1 \&$ isAllowed $=\mathrm{y}$ ).

\section{Eligibility Criteria}

Primary research articles of any study design were eligible for inclusion, with the exception of case series and case studies, which were excluded. Studies could have been either descriptive or analytic and include at least one variable related to transport of young calves as an intervention (trials) or exposure (observational studies), or examined the impact of any intervention (e.g., fluid therapy or anti-inflammatory medication) on a population of calves undergoing transport. Young dairy calves were defined as dairy, veal, or dairy-beef calves of any dairy breed or sex that were less than $60 \mathrm{~d}$ of age or weighing less than $100 \mathrm{~kg}$ at time of transportation. Articles also must have been written in English but no geographical or date restrictions were placed on the search. No minimum word count was required.

\section{Information Sources}

Eight databases were searched for potentially relevant articles: CAB Direct (via CABI), Scopus, ProQuest dissertation and theses, Agricola (via ProQuest), Medline (via Ovid), Science Citation Index Expanded (Sci-Expanded), Conference Proceedings Citation Index-Science (CPCI-S), and Emerging Sources Citation Index (ESCI; via Web of Science). No date restrictions were placed on the articles aside from that of the databases themselves.

\section{Literature Search}

The literature search of all databases was completed on June 29, 2020, using search terms related to calves and transportation, with the goal of maximizing sensitivity. The full search is shown in Table 1, which was formatted accordingly for each database. References were then uploaded to Endnote X9 reference management software (Clarivate Analytics) where duplicates were identified and removed. Once deduplication was completed, references were uploaded to DistillerSR 
Table 1. Search strings used to identify primary research articles evaluating transportation of young calves

\begin{tabular}{ll}
\hline No. & Search terms \\
\hline 1 & Calf or calves or suckler \\
2 & $\begin{array}{l}\text { Transport or transportation or drover or truck or trailer } \\
\text { or arrival or driving }\end{array}$ \\
3 & 1 AND 2 \\
\hline
\end{tabular}

(Evidence Partners Inc.), where references were deduplicated again before screening and data extraction were completed (Figure 1).

\section{Selection of Evidence}

Two levels of screening were conducted in duplicate by 2 independent reviewers (HMG, JD, TU, KC). Initial relevance screening evaluated the title and abstract of all records for potential eligibility. The following questions were used for screening articles at this level:

1. Is the title/abstract in English?

2. Does the title/abstract identify a primary research article (not a review, case report, or case series)?

3. Does the title/abstract describe transport of young calves (less than $60 \mathrm{~d}$ of age or less than $100 \mathrm{~kg})$ ?

The first 100 articles were pretested to ensure reviewers answered questions consistently. Articles were reviewed independently using the questions above and disagreement at the form level was resolved by consensus or mediation by DLR or CBW if consensus could not be reached. Articles that received "yes" or "unclear" to all 3 questions were included in the next level of screening.

At the second level of screening, 2 independent reviewers (HMG, JD, TU) assessed the full text of the article for eligibility using a list of questions that could only be answered by "yes" or "no." Disagreement at this level was resolved by consensus with mediation by DLR or CBW. The first 20 articles were pretested to ensure understanding of the questions by all reviewers. Articles with a "yes" to all 4 questions were eligible for data extraction. Reasons for exclusion at this level were reported (Figure 1). The questions used for screening the full text of the articles were:

1. Is the full-text article available in English?

2. Does the full-text article describe a primary research study?

3. Does the full-text article investigate or describe transport of calves under $60 \mathrm{~d}$ of age or less than
$100 \mathrm{~kg}$ (including dairy, dairy-beef, veal; excluding beef)?

4. Does the full-text article describe behavioral or physiological variables or morbidity or mortality in transported calves?

\section{Data Extraction}

Two reviewers independently extracted data from each of the included full-text studies (HMG, TU, KC). All reviewers pretested 5 references to ensure consistency and understanding. Disagreement at this level was resolved by discussion and consensus, with disagreements mediated by DLR or CBW. Authors were not contacted to request missing data or clarify results. Data extracted at this level included:

1. Study characteristics (year of publication, year conducted, and country where the study was completed)

2. Objective and hypotheses of the study

3. Study design

4. Study population (breed of calves, sample size, sex, production type, number of farms included, age of calves at enrollment, age of calves at transportation)

5. Interventions or risk factors examined (variables measured or compared between groups)

6. Outcomes evaluated and time at risk

\section{Synthesis of Results}

Data extracted from the included references were exported from DistillerSR to an Excel spreadsheet (version 16.54; Microsoft Corp.), summarized using descriptive statistics, and recorded in a table. Study characteristics that were summarized included publication date, target population, sample size, and study approach. Results extracted from studies included the definition of transport, morbidity, and any health parameters evaluated. A map was used to demonstrate the scope of geographical areas where the studies were conducted, and a line graph was used to show the total number of included studies published by year.

\section{Charting Process}

The selection and inclusion process were reported following the Preferred Reporting Items for Systematic Review and Meta-analysis (PRISMA; Moher et al., 2009). Summaries of included studies were compiled in frequency tables to describe study characteristics and target populations (Tables 2, 3, 4, 5, 6, and 7). 


\section{RESULTS}

\section{Search Results}

Flow of records through the screening process is described in Figure 1. The initial search returned 10,943 references. After deduplication, 6,859 unique references were included for title and abstract screening. At this first level, 6,500 articles were excluded, leaving 361 full-text articles that were assessed for eligibility at the second level of screening. Studies were excluded at the full-text level if they were not available in English (n =
190), did not describe a primary research article $(\mathrm{n}=$ 14), did not investigate or describe transport of calves under $60 \mathrm{~d}$ of age or less than $100 \mathrm{~kg}(\mathrm{n}=92)$, or did not describe behavioral or physiological variables or morbidity or mortality in transported calves ( $\mathrm{n}=$ 14). A total of 46 articles remained for inclusion in this scoping review.

\section{Study-Level Characteristics}

Included studies were published within the years 1973 to 2020 (Figure 2). The most commonly used
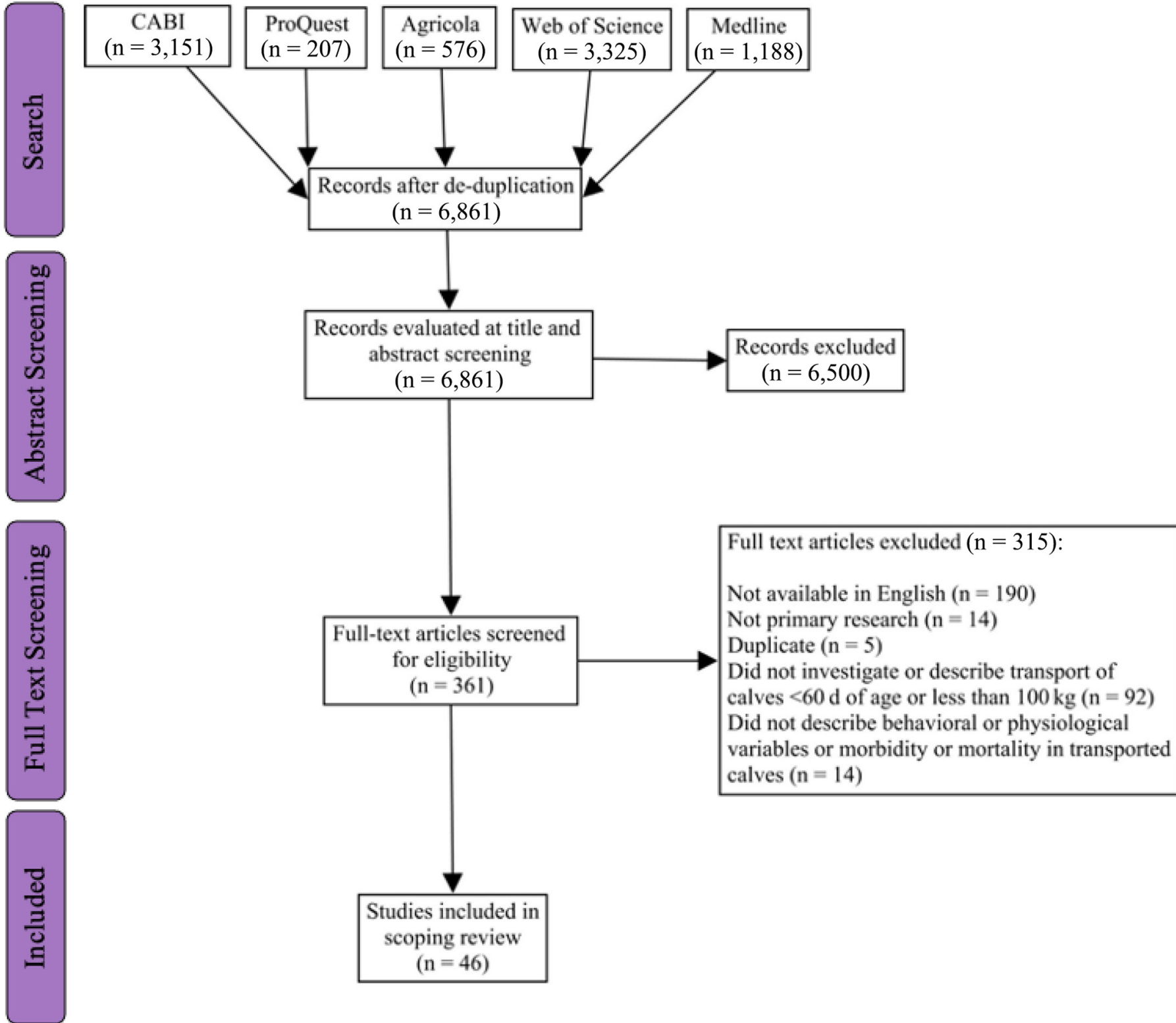

Figure 1. Preferred Reporting Items for Systematic Reviews and Meta-Analysis (PRISMA) flowchart (Liberati et al., 2009), demonstrating the search process for a scoping review of studies surrounding calf transportation. 

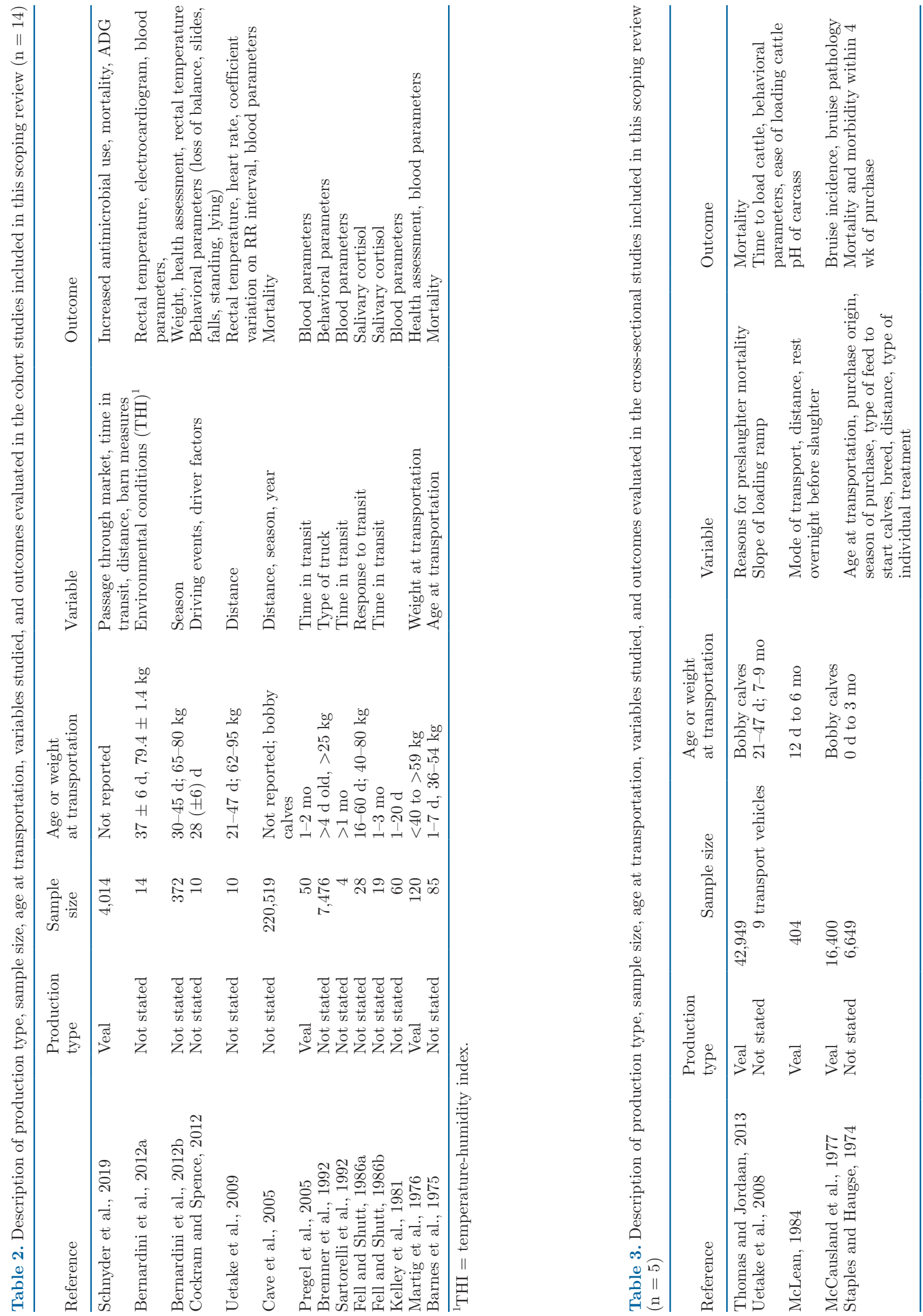


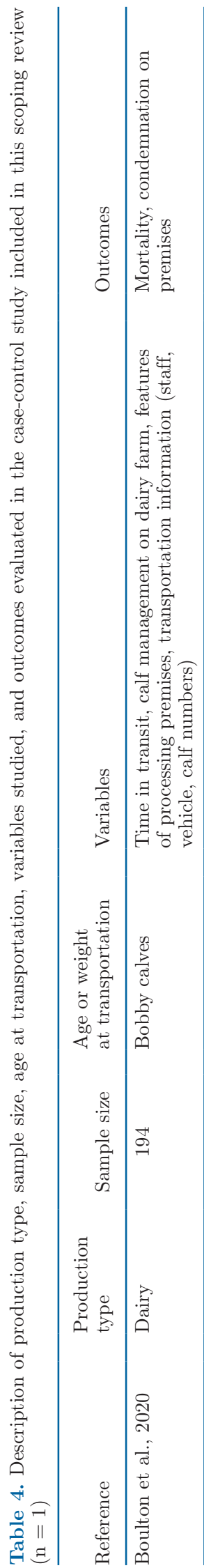

study design was experimental $(\mathrm{n}=26)$, and of these, 13 randomized calves to treatments, 1 did not randomize calves, and 12 did not report if random allocation was used. Other study types included cohort $(\mathrm{n}=14)$, cross-sectional $(\mathrm{n}=5)$, and case-control studies $(\mathrm{n}=$ 1).

Thirteen countries were represented in the studies retained in this scoping review (Figure 3). Specifically, research was conducted in Australia $(\mathrm{n}=3)$, Belgium $(\mathrm{n}=1)$, Finland $(\mathrm{n}=1)$, France $(\mathrm{n}=2)$, Italy $(\mathrm{n}=$ $3)$, Germany $(\mathrm{n}=1)$, the Netherlands $(\mathrm{n}=2)$, Poland $(\mathrm{n}=2)$, Japan $(\mathrm{n}=3)$, New Zealand $(\mathrm{n}=3)$, Switzerland $(\mathrm{n}=2)$, the United Kingdom $(\mathrm{n}=1)$, and the United States $(\mathrm{n}=5)$. Four studies were conducted in more than one country. The majority of included studies, however, did not report the country they were conducted in $(\mathrm{n}=20)$.

\section{Study Population Characteristics}

The majority of studies investigated transportation of Holstein-Friesian calves $(\mathrm{n}=26)$, whereas others studied cross-bred calves $(\mathrm{n}=12)$, Jersey calves $(\mathrm{n}=$ $3)$, Finnish Ayrshire $(\mathrm{n}=1)$, Guernsey $(\mathrm{n}=1)$, and a mix of breeds that were not stated $(\mathrm{n}=3)$. Cross-bred calves included Garonnaise crosses $(\mathrm{n}=1)$, Wagyu $\times$ Holstein-Friesian $(\mathrm{n}=3)$, or stated that calves were cross-bred but did not describe the crosses $(\mathrm{n}=8)$. Nine studies did not state the breed.

Transportation of male calves was most studied $(\mathrm{n}=$ 17), followed by both sexes $(\mathrm{n}=14)$, and female calves $(\mathrm{n}=2)$. Similar to other characteristics, many studies did not report sex of the calves $(\mathrm{n}=13)$. Production type of calves was also frequently not reported $(\mathrm{n}=$ $34)$. Of those that did, dairy $(\mathrm{n}=6)$ and veal $(\mathrm{n}=7)$ calves were most common. Calves were sourced from commercial $(\mathrm{n}=15)$ or research $(\mathrm{n}=4)$ facilities, as well as auction markets $(\mathrm{n}=6)$. Twenty-two studies did not report the source of the calves.

Age at transportation varied widely, although most studies included calves less than 1 mo old $(\mathrm{n}=31)$. Ten studies examined calves greater than 1 mo of age and 4 did not report the age at transportation but stated that they were "bobby calves." If age at transportation was not reported, studies met the inclusion criteria if they reported weight of the calves at the time of transportation, which ranged from 11 to $121 \mathrm{~kg}$. Some studies included calves beyond the age and weight criteria but were included if calves within the age and weight criteria were studied $(\mathrm{n}=6)$.

\section{Risk Factors or Interventions Studied}

The most frequent risk factor studied was time in transit $(\mathrm{n}=13)$, which ranged from 5 to $24 \mathrm{~h}$. Distance 
Goetz et al.: TRANSPORTATION OF YOUNG CALVES

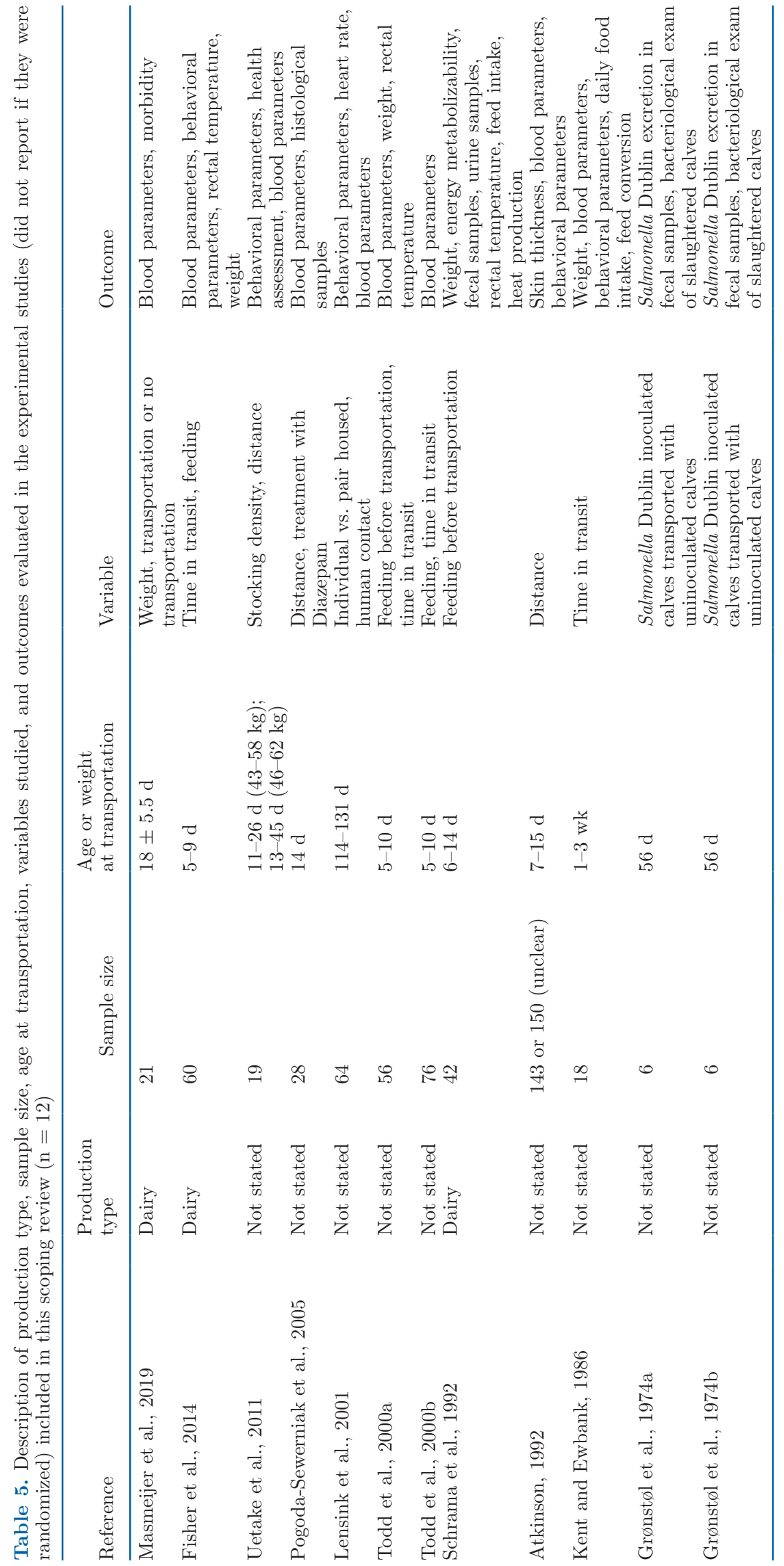


of transportation was also frequently studied $(\mathrm{n}=8)$ and ranged from 0 to $1,572 \mathrm{~km}$. Vehicle-related factors were less commonly studied. Two studies evaluated the type of trailer (open vs. conditioned; position of the deck on the trailer; Marcato et al., 2020; Bremner et al., 1992), and factors such as driver (Cockram and Spence, 2012), flooring type (Jongman and Butler, 2014), journey stage (the journey was divided into 2 stages of equal duration before and after the driver rest break; Cockram and Spence, 2012), mode of transport (road or rail; McLean, 1984), and incline and height of the vehicle were assessed in one study each (Bremner et al., 1992).

\section{Feeding $(n=8)$}

Feeding surrounding transportation was evaluated in 8 studies, 4 of which investigated plane of nutrition before transportation, 2 evaluated feeding during transport, one compared feeding $1.5 \mathrm{~L}$ of milk replacer (125 g of milk powder/L) or $1.5 \mathrm{~L}$ of electrolytes (20 g electrolytes/L of water) before transport, and one compared long-term starvation to a combination of varying transport duration and $30 \mathrm{~h}$ of starvation. In one study, volume of milk replacer and feeding frequency were investigated in calves allocated to one of 8 treatments. All groups were fed $50 \mathrm{~mL} / \mathrm{kg}$ of milk replacer, with the exception of a group that received $25 \mathrm{~mL} / \mathrm{kg}$, at the start of the experimental period and again $31 \mathrm{~h}$ later. The control group and $12 \mathrm{~h}$ transport group were fed again at $13 \mathrm{~h}$ after the onset of transportation and the group subjected to $3 \mathrm{~h}$ of transport was fed again at $4 \mathrm{~h}$, all with $50 \mathrm{~mL} / \mathrm{kg}$ (Todd et al., 2000a). Another study also studied 2 different feeding methods before transportation, where calves were fed below or near the maintenance requirement of milk replacer with the "low" feeding level receiving $19 \mathrm{~g}$ of powder/ $\mathrm{kg}$ and the "high" feeding level receiving $25 \mathrm{~g} / \mathrm{kg}$ (Schrama et al., 1992). Similarly, Schrama et al. (1996) fed calves milk replacer intended to be 0.7 and 1.1 times the metabolizable energy requirements for maintenance before transportation. Marcato et al. (2020) compared calves fed $1.5 \mathrm{~L}$ of rearing milk (125 g of milk powder/L) to calves fed a mixture of electrolytes (20 g of electrolytes/L of water) dissolved in $1.5 \mathrm{~L}$ of water before transportation for 6 or $18 \mathrm{~h}$ in an open or conditioned truck. The 2 studies considering feeding during transportation studied calves transported for 8, 16, 19, and $24 \mathrm{~h}$ (Knowles et al., 1997, 1999). Knowles et al. (1997) transported calves for 8,16 , and $24 \mathrm{~h}$ with calves in the 16 - and 24-h groups being fed a glucose and electrolyte solution at 8-h intervals; this trial was then repeated, without a stop for food. Another study evaluating a rest stop during a 19-h journey offered one group of calves $1 \mathrm{~L}$ 
Goetz et al.: TRANSPORTATION OF YOUNG CALVES

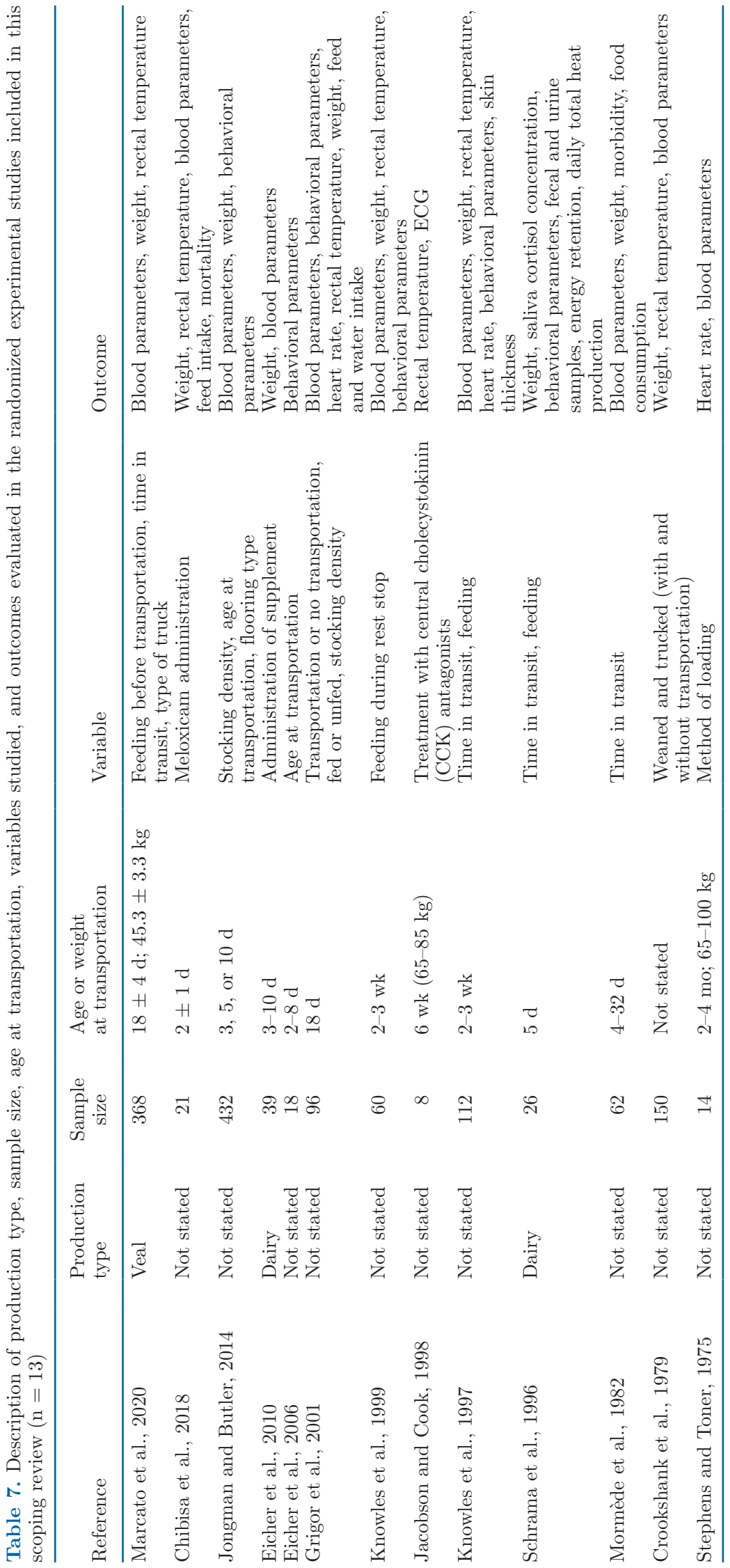


of water per calf, another group of calves were offered $2 \mathrm{~L}$ of warm glucose and electrolyte solution, and one group was offered no food or water during the rest stop approximately $9 \mathrm{~h}$ into transit (Knowles et al., 1999). Fisher et al. (2014) simulated various transport scenarios which calves may be subjected to by allocating calves to one of 4 treatments: no transit and no feed for $30 \mathrm{~h}$, no feed for $30 \mathrm{~h}$ including $6 \mathrm{~h}$ of transit to a new environment, no feed for $30 \mathrm{~h}$ including $12 \mathrm{~h}$ of transit to a new environment, and no feed for $30 \mathrm{~h}$ including transit for $1 \mathrm{~h}$ to a holding pen, remaining there for $6 \mathrm{~h}$, then transport for $5 \mathrm{~h}$ to a new environment.

\section{Age at Transportation $(n=4)$}

Although the age at transportation varied greatly among studies, only 4 examined age as a risk factor. These studies transported calves at 1, 2, 3, or $4 \mathrm{~d}$ of age (Barnes et al., 1975); 2 to 3, 4 to 5,6 to $8 \mathrm{~d}$ of age (Eicher et al., 2006); and up to 1 wk old, 8 to 14 d, 15 to $21 \mathrm{~d}$, over $3 \mathrm{wk}$, and mixed ages of $1 \mathrm{wk}$ to 3 mo (Staples and Haugse, 1974). In addition, Kent and Ewbank (1986) compared the effect of 6- and 18-h journeys on calves 1 to 3 wk of age compared with 6-mo-old calves.

\section{Medication Administration}

Administration of a medication or supplement to mitigate transport-related stress was evaluated in 4 studies. Specifically, Chibisa et al. (2018) randomly assigned calves to one of 2 treatments where calves received oral meloxicam (1 mg/kg of BW; Carlsbad Technologies Inc.) or a control of oral whey protein (1 $\mathrm{mg} / \mathrm{kg}$ of $\mathrm{BW}$, excipient used in the manufacture of meloxicam tablets; Nature's Best). Diazepam administration $(1 \mathrm{mg} / \mathrm{kg}$ of $\mathrm{BW}, 0.5 \mathrm{~h}$ before transportation and once per day for subsequent $5 \mathrm{~d}$ ) was also studied (Pogoda-Sewerniak et al., 2005). Treatment with central cholecystokinin (CCK) antagonists was evaluated to determine the psychological contribution to stress induced by transportation (Jacobson and Cook, 1998). Eicher et al. (2010) also administered $113 \mathrm{~g}$ of a $1.8 \%$ $\beta$-glucan derivative of yeast cell walls plus $250 \mathrm{mg}$ of L-ascorbic acid phosphate (BG2) or $150 \mathrm{mg}$ of purified $\beta$-glucan fraction from yeast cell walls (approximately

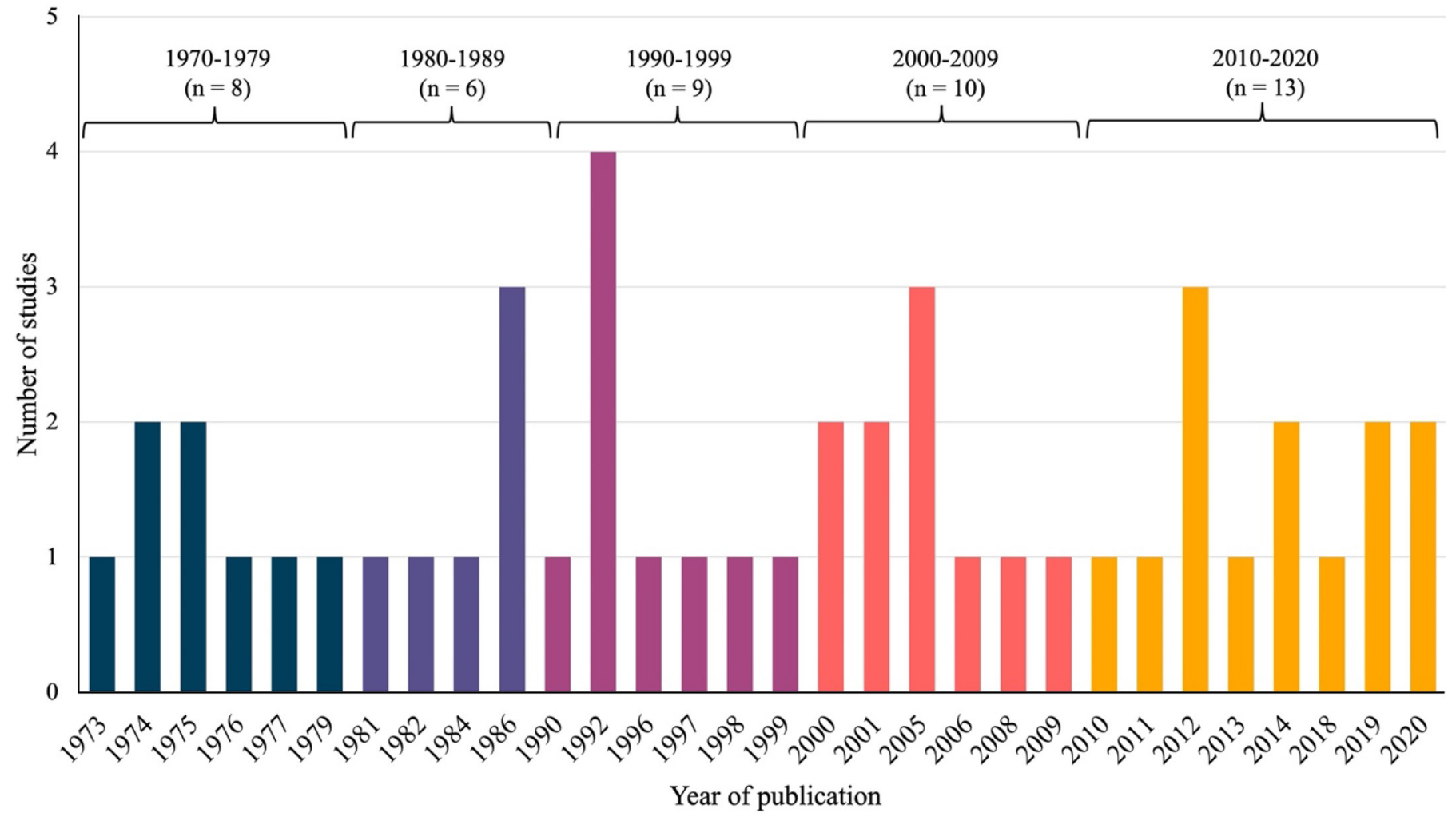

Figure 2. The number of studies evaluating transportation of calves included in this scoping review by year of publication (colors indicate decades). 
$70 \% \beta$-glucan) plus $250 \mathrm{mg} /$ feeding of L-ascorbic acid phosphate (BG70) as supplements to mediate transport stress.

\section{Stocking Density $(n=3)$}

Three studies evaluated how stocking density influenced the effect of transportation. Specifically, Grigor et al. (2001) transported calves at a space allowance of $0.375 \mathrm{~m} 2 /$ head or $0.475 \mathrm{~m} 2 /$ head, whereas Jongman and Butler (2014) were aiming to identify the space allowance requirements for transport of bobby calves and transported calves at $0.2,0.3$, or $0.5 \mathrm{~m}^{2} /$ head. Uetake et al. (2011) also investigated stocking density, evaluating the recommendations of the European Union and compared stocking densities of $0.25,0.35$, and $0.45 \mathrm{~m}^{2} /$ head.

\section{Additional Risk Factors}

Other risk factors and interventions were less frequently studied. Inoculation with Salmonella Dublin (n = 2; Grønstøl et al., 1974a,b) as well as calf management before transportation (Boulton et al., 2020), environmental conditions (Bernardini et al., 2012a,b), individual compared with pair-housed calves (Lensink et al., 2001), passage through markets (Schnyder et al., 2019), purchase origin (Staples and Haugse, 1974), type of feed to start calves (Staples and Haugse, 1974), breed (Staples and Haugse, 1974), flooring type (Jongman and Butler, 2014), and rest overnight before slaughter (McLean, 1984) were investigated in one study each.

\section{Outcomes Assessed}

Individual studies evaluated between one to 6 outcomes. Specifically, a single outcome was used to evaluate the impact of transportation in 12 studies, 15 studies used 2 outcomes, 11 used 3 outcomes, 2 studies used 4 outcomes, 4 studies included 5 outcomes, and the remaining 2 studies used 6 outcomes.

Hematologic Parameters $(n=28)$. The most common method of evaluating how calves responded to transportation was by using blood parameters, and a full list of these is summarized in Table 8. More common metrics included glucose $(\mathrm{n}=13)$, nonesterified fatty acids (NEFA) $(\mathrm{n}=9)$, creatine kinase $(\mathrm{n}=9)$, cortisol ( $\mathrm{n}=9)$, serum iron $(\mathrm{n}=9)$, BHB $(\mathrm{n}=7)$, calcium $(\mathrm{n}=7)$, norepinephrine $(\mathrm{n}=7)$, serum total protein $(\mathrm{n}=7)$, triiodothyronine (T3) $(\mathrm{n}=7)$, aspartate aminotransferase (AST) $(\mathrm{n}=6)$, albumin $(\mathrm{n}=5)$, hematocrit $(\mathrm{n}=5)$, potassium $(\mathrm{n}=5)$, lactate $(\mathrm{n}=5)$, sodium $(\mathrm{n}=5)$, and packed cell volume $(\mathrm{n}=4)$.

Health Assessments $(n=21)$. Studies assessing health frequently used rectal temperature $(\mathrm{n}=10)$, heart rate $(n=6)$, electrocardiogram data $(n=2)$, skin thickness $(\mathrm{n}=1)$, or skin elasticity $(\mathrm{n}=1)$ to determine calf health. In the 7 studies that measured heart rate, all recorded heart rate during transportation, whereas only one monitored heart rate before,

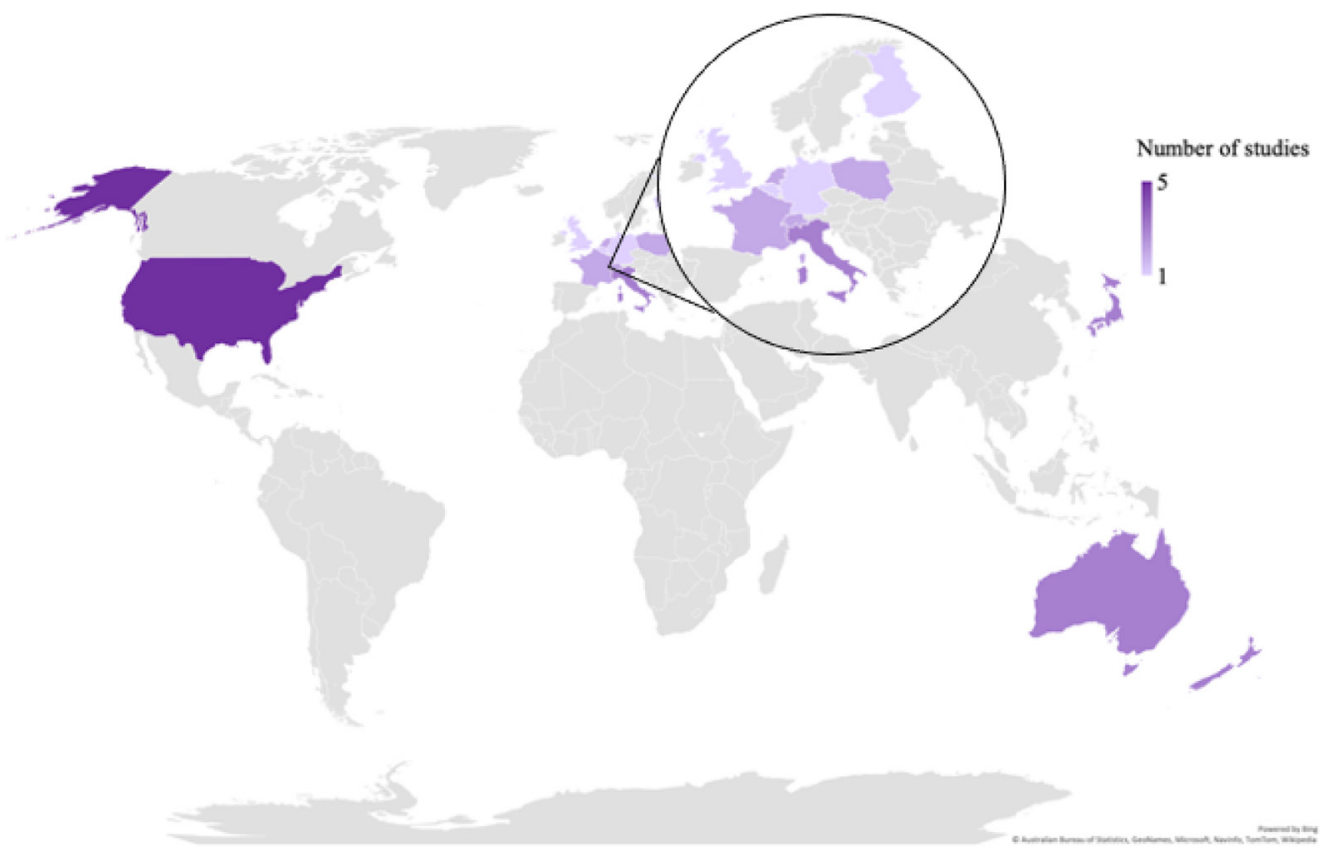

Figure 3. World map indicating where studies of calf transportation that were included in this scoping review were conducted. 
Table 8. List of blood parameters and the number of calf transportation studies that included them to evaluate the impact of transportation

\begin{tabular}{|c|c|}
\hline Parameter & $\begin{array}{l}\text { Number } \\
\text { of studies }\end{array}$ \\
\hline 3-Methylhistidine & 1 \\
\hline Alanine aminotransferase (ALT) & 4 \\
\hline Albumin & 5 \\
\hline Alkaline phosphatase & 2 \\
\hline Amino acids & 1 \\
\hline Antioxidant capacity & 1 \\
\hline Aspartate aminotransferase (AST) & 6 \\
\hline Basophils & 1 \\
\hline $\mathrm{BHB}$ & 7 \\
\hline $\begin{array}{l}\text { Blastogenesis of primary peripheral blood mononuclear } \\
\text { cell cultures }\end{array}$ & 1 \\
\hline C-reactive protein & 1 \\
\hline Calcium & 7 \\
\hline Catecholamine & 1 \\
\hline Chloride & 3 \\
\hline Cholesterol & 3 \\
\hline Copper & 1 \\
\hline Corticosteroids & 2 \\
\hline Cortisol & 9 \\
\hline Creatine & 2 \\
\hline Creatine kinase & 9 \\
\hline Differential leukocyte counts & 1 \\
\hline Dopamine & 1 \\
\hline Eosinophils & 1 \\
\hline Epinephrine & 2 \\
\hline Erythrocyte counts & 4 \\
\hline Free fatty acids & 1 \\
\hline$\gamma$-Glutamyl transferase & 2 \\
\hline Glucose & 13 \\
\hline Granulocytes & 1 \\
\hline Haptoglobin & 1 \\
\hline Hematocrit & 5 \\
\hline Hemoglobin & 2 \\
\hline $\operatorname{IgG}$ & 1 \\
\hline IgM & 1 \\
\hline Immunoglobulins & 1 \\
\hline Inorganic phosphorus & 2 \\
\hline IL-17A & 1 \\
\hline Lactate & 5 \\
\hline Lactic acid & 2 \\
\hline Lactate dehydrogenase & 3 \\
\hline Leukocyte count & 5 \\
\hline Lymphocytes & 1 \\
\hline Lymphocyte stimulation assay & 1 \\
\hline Magnesium & 3 \\
\hline Mean corpuscular hemoglobin & 2 \\
\hline Monocytes & 2 \\
\hline Sodium & 5 \\
\hline Nonesterified fatty acids (NEFA) & 9 \\
\hline Neutrophils & 2 \\
\hline Norepinephrine & 7 \\
\hline Osmolality & 3 \\
\hline Packed cell volume & 4 \\
\hline Peripheral blood mononuclear cells (PBMC) & 1 \\
\hline Phosphorus & 1 \\
\hline Plasma gamma-globulin & 1 \\
\hline Potassium & 5 \\
\hline Red blood cells & 2 \\
\hline Red cell distribution width & 1 \\
\hline Serum BHV-1 antibody titer & 1 \\
\hline Serum iron & 9 \\
\hline Serum ovalbumin antibody titer & 1 \\
\hline Serum $\mathrm{pH}$ & 1 \\
\hline Serum total protein (STP) & 7 \\
\hline
\end{tabular}

Table 8 (Continued). List of blood parameters and the number of calf transportation studies that included them to evaluate the impact of transportation

\begin{tabular}{lc}
\hline Parameter & $\begin{array}{c}\text { Number } \\
\text { of studies }\end{array}$ \\
\hline Total iron-binding capacity & 1 \\
Tumor necrosis factor- $\alpha$ & 1 \\
Total bilirubin & 1 \\
Total plasma protein & 2 \\
Triglycerides & 3 \\
Triiodothyronine (T3) & 7 \\
Urea & 2 \\
Urea nitrogen & 3 \\
Uric acid & 3 \\
Zinc & 1 \\
\hline
\end{tabular}

during, and for a short period following transportation. Only one study stated that calves were clinically examined but the scoring system used to examine the calves was not described (Martig et al., 1976). Another study assessed calves for injury during transit or calves that developed watery feces (Uetake et al., 2011).

Body Weight $(n=17)$. Although this metric was commonly evaluated, the method of weighing calves was rarely described. Two studies stated that a scale was used, however the remaining 15 did not describe the method used to measure weight. Frequency of weighing also varied. Many studies reported weighing calves immediately before, immediately after, and over a period following transportation $(\mathrm{n}=9)$. When calves were weighed multiple times following transportation, the time of follow up ranged from $96 \mathrm{~h}$ to $28 \mathrm{~d}$. Only 4 studies weighed calves immediately before and immediately after transportation without monitoring weight at additional time points after transport. Average daily gain was also measured in 3 studies. These studies calculated ADG from 1 to $4 \mathrm{~d}$ after arrival (Chibisa et al., 2018), 1 to $28 \mathrm{~d}$ after arrival (Eicher et al., 2010), and during the fattening period (Schnyder et al., 2019).

Behavior $(n=14)$. When behavioral parameters were used to evaluate the effect of transportation $(\mathrm{n}=$ 14), researchers studied behaviors before $(\mathrm{n}=5)$, during $(\mathrm{n}=5)$, and following $(\mathrm{n}=8)$ transportation. Behaviors studied were lying time $(\mathrm{n}=5)$, standing time $(\mathrm{n}=$ $2)$, ruminating $(\mathrm{n}=1)$, occurrence of turning around ( $\mathrm{n}$ $=1)$, loss of balance $(\mathrm{n}=1)$, slides $(\mathrm{n}=1)$, falls $(\mathrm{n}=$ $1)$, and sleeping $(\mathrm{n}=1)$. Grigor et al. (2001) monitored behavior $24 \mathrm{~h}$ before, during 2 journeys, during lairage, and $24 \mathrm{~h}$ following transportation for behaviors such as standing, moving, lying, eating straw, drinking milk substitute, drinking water, oral investigation (licking or sniffing the pen walls), ruminating, self-grooming, and interacting with other calves. Knowles et al. (1997) monitored standing time for $24 \mathrm{~h}$ before, during, and 24 
$\mathrm{h}$ after transportation. The longest that calf behavior was continuously monitored following transportation was for $48 \mathrm{~h}$ which was conducted by Knowles et al. (1999) who monitored lying and standing time for $24 \mathrm{~h}$ before, during, and $48 \mathrm{~h}$ after transportation. A single study evaluated lying during transport and lying and drinking for $12 \mathrm{~h}$ after transportation (Jongman and Butler, 2014) and one study monitored standing and lying position one day before and during transportation (Schrama et al., 1996). One study was focused solely on behaviors during loading and observed kneeling, slipping, balking, backing down, moving sideways, turning around, jumping, defecating, or urinating (Uetake et al., 2008). Another study focused on behaviors during unloading, specifically assessing whether calves walked or ran, with or without minor slipping or sliding, with or without falling, and if calves were not able to sit or stand at any stage of unloading, which were classified as "down" (Bremner et al., 1992). Unlike the previous studies investigating behaviors in response to transportation, Eicher et al. (2006) evaluated the effects of age at transport on behavioral responses to novel stimuli 6 weeks following transportation. In this test, calves were placed in a corridor with several novel objects placed $2.4 \mathrm{~m}$ apart including an entry to the corridor, red bucket, black mat, translucent plastic curtain, horizontal striped plant, darkened space, silver gates, reflecting metal, and open red gate to finish. The force to navigate this corridor was scored $(1=$ yelling; $2=$ moving into flight path; $3=$ pats; or $4=$ pushing to pass the obstacle).

Mortality $(n=7)$. Studies evaluating mortality looked at either short- or long-term death loss. Mortality was defined as either dead on arrival to an abattoir ( $\mathrm{n}=2$; Boulton et al., 2020; Thomas and Jordaan, 2013), condemned on arrival or in yard at the processing premises (e.g., weak, recumbent, thin body condition; n $=1$; Boulton et al., 2020), euthanized at antemortem examination ( $\mathrm{n}=1$; Thomas and Jordaan, 2013), dead soon after arrival to an abattoir $(\mathrm{n}=2$; Cave et al., 2005; Boulton et al., 2020), or in longer term studies, within $10 \mathrm{~d}(\mathrm{n}=1$; Chibisa et al., 2018), $4 \mathrm{wk}(\mathrm{n}=1$; Staples and Haugse, 1974), or $60 \mathrm{~d}$ after transportation ( $\mathrm{n}=1$; Barnes et al., 1975).

Morbidity $(n=4)$. Morbidity associated with transportation was evaluated in 4 studies. The definition of morbidity and the time at risk for morbidity following transportation both varied greatly. One study followed calves for $72 \mathrm{~h}$ following transportation (Masmeijer et al., 2019), whereas the other 3 studies followed calves for longer. Specifically, they were followed for $20 \mathrm{~d}, 3 \mathrm{wk}$, and $4 \mathrm{wk}$ after transportation (Staples and Haugse. 1974; Mormède et al., 1982; Grigor et al., 2001). With respect to definitions of morbidity,
Masmeijer et al. (2019) focused on calves developing diarrhea, however, the method of scoring was not described. Grigor et al. (2001) evaluated calves daily for development of clinical signs of respiratory disease, diarrhea, or dehydration. In this study, respiration rate, ocular and nasal discharges, inflammation and lesions of the nasal mucous membranes and conjunctiva, and presence of cough and salivation were considered signs of respiratory illness. Diarrhea was evaluated by scoring fecal consistency and dehydration was determined using skin elasticity and presence of sunken eyes. Mormède et al. (1982) rated disease according to frequency and severity. Benign diarrhea or respiratory signs were given a score of 1 ; umbilical infection, profuse diarrhea, or respiratory disease with therapeutic interventions were given a score of 3. Staples and Haugse (1974) were also interested in morbidity within the 4 wk of purchase; however, morbidity was defined as the number of calves "sick," which was indicated by calf purchasers in response to a questionnaire.

Additional Outcomes. These were evaluated less frequently and included, daily food intake $(\mathrm{n}=3$; Schrama et al., 1992; Grigor et al., 2001; Chibisa et al., 2018), energy metabolism ( $\mathrm{n}=2$; Schrama et al., 1992 , 1996), urine samples $(\mathrm{n}=2)$ (Schrama et al., 1992, 1996), bacteriological exam of slaughtered calves (Grønstøl et al., 1974b), bruise incidence and pathology (McCausland et al., 1977), daily total heat production (Schrama et al., 1996), energy retention (Schrama et al., 1996), feed conversion (Kent and Ewbank, 1986), forcible operations of transporters (pushing, heaving, shoving, twisting tail, hitting, kicking; Uetake et al., 2008), heat production (Schrama et al., 1992, 1996), antimicrobial use (Schnyder et al., 2019), pH of carcass (McLean, 1984), postmortem findings (Thomas and Jordaan, 2013), Salmonella Dublin isolation from carcass (Grønstøl et al., 1974a), Salmonella Dublin excretion in feces (Grønstøl et al., 1974b), and time to unload cattle (Bremner et al., 1992).

\section{DISCUSSION}

This scoping review aimed to describe and characterize descriptive and analytic studies examining transportation of young dairy calves, including how the effect of transport has been assessed and evaluated, and identify knowledge gaps in the literature. References included in this review demonstrated a stagnant body of literature spanning primarily North America. Despite the range in year of publication extending across nearly 5 decades, the research activity in this field has not been increasing over time. Several knowledge gaps were identified and many aspects of calf transportation have yet to be well understood. 


\section{Age at Transportation}

Several countries are interested in establishing regulations which stipulate a minimum age at transportation. For example, in Canada, calves $\leq 8 \mathrm{~d}$ of age may only be transported once and not to an assembly center (Government of Canada, 2020). The minimum age for transportation is 4,5 , and $14 \mathrm{~d}$ of age in New Zealand, Australia, and the European Union, respectively, with calves $<10 \mathrm{~d}$ old allowed to travel a maximum of $100 \mathrm{~km}$ in the European Union (Council of the European Union, 2004; Animal Health Australia, 2012; New Zealand Government, 2018). However, few studies investigated how age at transportation affected calves' response to transportation. In fact, only 2 included calves 8 d of age or less (Staples and Haugse, 1974; Eicher et al., 2006). One (Staples and Haugse, 1974) was a cross-sectional study conducted almost 50 years ago that requested calf purchasers to report via questionnaire how many calves died or became sick within 4 wk of purchase. More recently, Eicher et al. (2006) conducted a randomized experimental study during which calves were transported at 2 to 3,4 to 5 , or 6 to $8 \mathrm{~d}$ of age. This study included a small sample size of 18 calves and only behavioral parameters 6 weeks following transportation were used to evaluate the impact of transportation.

\section{Time in Transit}

The most frequent risk factor studied was time in transit $(\mathrm{n}=13)$; however, only 3 of these studies compared $12 \mathrm{~h}$ of time in transit to another length of time (Todd et al., 2000a,b; Fisher et al., 2014). Extending the time off feed beyond the daily feeding interval, regardless of whether the calves were transported or not, resulted in a similar reduction of blood glucose concentrations suggesting that the effect of transportation duration was not beyond that of food deprivation alone (Fisher et al., 2014). However, behavioral indicators of hunger were not studied. Regulations should focus on the ability to provide food and water in addition to the total amount of time that calves are transported. In the United States, calves can be transported for up to $28 \mathrm{~h}$ without feed or water until they must be unloaded for a rest break (United States Government, 2011). The rest break requires calves to be unloaded into pens equipped for feeding, water, and rest for at least $5 \mathrm{~h}$ (United States Government, 2011). Calves transported in Canada may be kept off feed and water and transported for up to $12 \mathrm{~h}$ before an 8-h rest period is required (Government of Canada, 2020). However, legislation focused on time in transit does not always align with the maximum duration calves are allowed to be off feed. Australia does not have legislation on maximum duration without feed, but calves may only be transported for $12 \mathrm{~h}$ until they must receive a break (Animal Health Australia, 2012). In the European Union, calves may be off feed for $19 \mathrm{~h}$ but can only be transported for $9 \mathrm{~h}$ at once (Council of the European Union, 2004). After receiving a 1-h break, calves may be transported another $9 \mathrm{~h}$ (Council of the European Union, 2004). In New Zealand, regulations state that calves may be off feed for $24 \mathrm{~h}$ and transported a maximum of $12 \mathrm{~h}$ (New Zealand Government, 2018). The lack of published data surrounding age at transportation and time in transit highlights an important aspect of calf transportation that warrants further exploration. Adequately powered and well-reported research that uses validated metrics to evaluate the effect of transportation would guide stakeholders in designing evidence-based transportation regulations.

\section{Mitigating the Effect of Transportation}

Despite the high frequency of calf transportation, methods of mitigating the impact of transportation through medication or supplementation were only investigated in 4 studies. It is well understood that transportation is particularly stressful for young calves and identifying methods to mitigate or manage the effect may be of great interest to calf raisers as calves face health challenges at their facilities following transportation (Scott et al., 2019). For example, Chibisa et al. (2018) identified a benefit of improved growth and intake of milk replacer when providing meloxicam to Jersey calves before an 8.5-h journey. Although this was conducted in a small group of calves, future research should consider its plausibility in reducing the effects of transportation on calf health. Another potential method to mitigate stress is to reduce stocking density during transit; however, its effect was infrequently studied in the articles included in this scoping review. Similarly, provision of bedding or a comfortable flooring may mitigate the stress of transport, yet flooring type was discussed in only one paper (Jongman and Butler, 2014). From this review, it is clear that there is a substantial knowledge gap surrounding how transportation conditions affect calves. Future research should investigate this area further and determine methods to mitigate the stress of transportation.

\section{Blood Parameters}

The most common method of evaluating the effect of transportation was measuring various blood param- 
eters $(\mathrm{n}=28)$. A total of 76 different hematological variables were included, and among the most frequently used were creatine kinase $(\mathrm{n}=9)$ and cortisol $(\mathrm{n}=9)$. Interpreting results from these parameters as a method of assessing the impact of transportation is challenging, namely due to limited data on reference ranges and changes in these parameters with age (Knowles et al., 2000). Furthermore, authors who identified unremarkable changes in the levels of cortisol suggested that these results may imply that calves were either unaffected by transportation or that they were unable to adapt physiologically to transportation in the way that mature animals are capable of (Knowles et al., 1997). However, serum cortisol is difficult to interpret as a marker of stress in calves due to several factors, namely its sensitivity to environmental factors such as handling, as well as its diurnal and seasonal rhythms in animals (Mormède et al., 2007). It tends to rise due to stressful stimuli and then return to baseline levels quickly due to the negative feedback loop, therefore making it better suited for evaluating acute experiences instead of chronic stress (Manteuffel, 2002). Creatine kinase has been described as increasing in response to trauma such as bruising, although studies have found conflicting results on the interpretation of this variable (Tarrant, 1990). It is possible that an increase in creatine kinase may serve as an indicator of tissue damage in diseased animals, but elevation in its concentration has also been associated with increased ADG and reduced hazard of morbidity (Boyd, 1983; Goetz et al., 2021). Given that blood parameters have been used extensively as a method to evaluate the impact of transportation, future research should instead focus on improving our understanding of additional measures that can be used to assess calves' responses to transportation.

\section{Morbidity, Mortality, and Growth}

Measuring blood parameters can provide some level of insight to the physiological response of calves; however, they should be interpreted cautiously and may be better used in addition to other clinically relevant measures of impact such as health and growth, especially when calves are young. Morbidity, mortality, and growth are important indicators of health and performance at calf-raising facilities, yet very little is known about the long-term effects of transportation on these measures. In addition, few studies investigated morbidity and mortality associated with transportation and those that did only followed calves for a short period of time after transport. To improve understanding and motivate change in transport practices, it's important that stakeholders are informed of relevant, measurable indicators, such as morbidity, mortality, and growth, that can be monitored at the farm level more easily.

\section{Behavioral Indicators}

Behavioral indicators were frequently used to evaluate calves' response to transportation in the studies included in this scoping review $(\mathrm{n}=14)$. Researchers most frequently observed the duration of lying $(\mathrm{n}=5)$ following transportation $(\mathrm{n}=8)$ to understand recovery and how calves coped physiologically with the experience of transportation. Such behaviors were visually observed in the studies included herein. Accelerometers could also be used to reliably quantify calf behavior as they have been validated for measuring lying time and show high agreement with visual observation (Trénel et al., 2009). These devices have been used to detect disease such as bovine respiratory disease, navel inflammation, and diarrhea, and have the potential to assess behaviors associated with positive or negative affective states, such as play behavior (Toaff-Rosenstein et al., 2016; Studds et al., 2018; Lowe et al., 2019). Despite the wide range of application and potential opportunities to use these devices, the studies identified in this scoping review used behavioral indicators to measure calves' physiological response to transportation and not their affective state. Future transportation research could use accelerometers to progress our understanding in this area.

\section{Number of Outcomes}

Most studies $(\mathrm{n}=34)$ used more than one outcome to evaluate calves' responses to transportation. Combining outcome measures may be valuable because certain parameters, such as blood parameters, must be interpreted differently depending on factors such as age, sex, or breed (Mohri et al., 2007). However, when studies evaluate different outcomes for the same conditions, combining, comparing, and interpreting results presents a challenge (Gargon et al., 2019). It's important to understand whether the study is powered to detect a difference in a particular outcome, and that when multiple outcomes are used, there is an increase in the likelihood of a type I error.

Additionally, there are many ways to define a given outcome, and the use of clinically relevant parameters is critical to inform stakeholder groups involved in decision making. The Core Outcome Measures in Effectiveness Trials initiative is led by a group of researchers with the common goal of combating discrepancies in outcome reporting in human health research using the 
development of core outcome sets. These core outcome sets represent the minimum that should be measured and reported in clinical trials of a specific condition and should also be a goal for animal health research topics such as calf transportation to improve the quality of conducted research.

\section{Limitations}

Eligibility criteria included the requirement that calves be under $60 \mathrm{~d}$ of age, or under $100 \mathrm{~kg}$ when age was not available. If this was not reported or calves exceeded this cut off, studies were excluded. With a high percentage of studies lacking information about the age or weight of calves at transportation, researchers could not determine if identified references met the eligibility requirements, and they were therefore excluded at the full text level $(\mathrm{n}=92)$. This is not surprising given that a recent review of animal health studies highlighted the trend of poor reporting and found that demographic and clinical characteristics were reported in only 37/137 (27\%) of studies (Winder et al., 2019). Additionally, only articles written in English were included and therefore, studies written in other languages were unable to be included. At the full text level, 190 studies were not written in English; however, many were excluded at title and abstract screening as well.

\section{CONCLUSIONS}

This scoping review describes the body of literature surrounding the transportation of young calves including what risk factors and interventions have been assessed, as well as how the effect of transportation has been measured. Not unlike other areas of research, there is a need for improved reporting of study conduct to better synthesize data in this field. Future work should explore methods to better prepare calves for transportation, such as improving nutrition or administering medication before transit, or transporting calves at an older age or weight. Researchers should implement the use of a priori study protocols and core outcome sets to provide more usable data to better inform stakeholders and ultimately improve calf health and welfare.

\section{ACKNOWLEDGMENTS}

The first author was supported by Dairy Farmers of Canada (Ottawa, ON, Canada), Veal Farmers of Ontario (Guelph, ON, Canada), and the Ontario Ministry of Agriculture, Food, and Rural Affairs through the OMAFRA Alliance program (Guelph, ON, Canada). The authors have not stated any conflicts of interest.

\section{REFERENCES}

Agnes, F., P. Sartorelli, B. H. Abdi, and A. Locatelli. 1990. Effect of transport loading or noise on blood biochemical variables on calves. Am. J. Vet. Res. 51:1679-1681.

Animal Health Australia. 2012. Australian Animal Welfare Standards and Guidelines - Land Transport of Livestock. Edition 1, Version 1.1. Canberra. http://www.animalwelfarestandards.net.au/files/ 2015/12/Land-transport-of-livestock-Standards-and-Guidelines -Version-1.-1-21-September-2012.pdf.

Arksey, H., and L. O'Malley. 2005. Scoping studies: Towards a methodological framework. Int. J. Soc. Res. Methodol. 8:19-32. https:/ /doi.org/10.1080/1364557032000119616.

Atkinson, P. J. 1992. Investigation of the effects of transport and lairage on hydration state and resting behaviour of calves for export. Vet. Rec. 130:413-416. https://doi.org/10.1136/vr.130.19.413.

Barnes, M. A., R. E. Carter, J. V. Longnecker, J. W. Riesen, and C. O. Woody. 1975. Age at transport and calf survival. J. Dairy Sci. 58:1247.

Bernardini, D., G. Gerardi, D. Degani, C. Guglielmini, and S. Segato. 2012b. Effects of ambient temperature on calf welfare parameters during long-road transportation. Pages 59-64 in Veterinary Science. Springer; 2012. https://doi.org/10.1007/978-3-642-23271-8 -10 .

Bernardini, D., G. Gerardi, A. Peli, L. Nanni Costa, M. Amadori, and S. Segato. 2012a. The effects of different environmental conditions on thermoregulation and clinical and hematological variables in long-distance road-transported calves. J. Anim. Sci. 90:1183-1191. https://doi.org/10.2527/jas.2011-4113.

Boulton, A. C., N. J. Kells, N. Cogger, C. B. Johnson, C. O'Connor, J. Webster, A. Palmer, and N. J. Beausoleil. 2020. Risk factors for bobby calf morality across the New Zealand dairy supply chain. Prev. Vet. Med. 174:104836. https://doi.org/10.1016/j.prevetmed .2019.104836.

Boyd, J. W. 1983. The mechanisms relating to increases in plasma enzymes and isoenzymes in diseases of animals. Vet. Clin. Pathol. 12:9-24. https://doi.org/10.1111/j.1939-165X.1983.tb00609.x.

Bremner, K. J., L. R. Mathews, D. J. Brears, and A. M. Painting. 1992. The Behaviour and Welfare of Calves During Unloading after Transportation. Pages 73-75 in the Proceedings of the New Zealand Society of Animal Production Vol 52, Canterbury, New Zealand.

Cave, J. G., A. P. L. Callinan, and W. K. Woonton. 2005. Mortalities in bobby calves associated with long distance transport. Aust. Vet. J. 83:82-84. https://doi.org/10.1111/j.1751-0813.2005.tb12203.x.

Chibisa, G. E., J. R. Vinyard, and A. H. Laarman. 2018. Short communication: Effects of meloxicam administration on protein metabolism and growth performance in transported Jersey calves. J. Dairy Sci. 101:11435-11440. https://doi.org/10.3168/jds.2018 $-14493$.

Cockram, M. S., and J. Y. Spence. 2012. The effects of driving events on the stability and resting behaviour of cattle, young calves and pigs. Anim. Welf. 21:403-417. https://doi.org/10.7120/09627286 .21.3.403.

Cole, N. A., T. H. Camp, L. D. Rowe, D. G. Stevens, and D. P. Hutcheson. 1988. Effect of transport stress in feeder calves. Am. J. Vet. Res. 49:179-183.

Council of the European Union. 2004. Council regulation (EC) number $1 / 2005$ on the protection of animals during transport and related operations and amending directives 64/432/EEC and 93/119/EC and Regulation (EC) No 1255/97. https://eur-lex.europa.eu/legal -content/EN/TXT/PDF/?uri=CELEX:32005R0001\&from=en.

Crookshank, H. R., M. H. Elissalde, R. G. White, D. C. Clanton, and H. E. Smalley. 1979. Effect of transportation and handling of calves upon blood serum composition. J. Anim. Sci. 48:430-435. https://doi.org/10.2527/jas1979.483430x.

Eicher, S. D., T. A. Johnson, and J. N. Marchant-Forde. 2006. Age at transport effects on behavioral responses in dairy calves to novel stimuli. J. Anim. Sci. 84:305.

Eicher, S. D., I. V. Wesley, V. K. Sharma, and T. R. Johnson. 2010. Yeast cell-wall products containing $\beta$-glucan plus ascorbic acid 
affect neonatal Bos taurus calf leukocytes and growth after a transport stressor. J. Anim. Sci. 88:1195-1203. https://doi.org/10 $.2527 /$ jas.2008-1669.

Fell, L. R., and D. A. Shutt. 1986a. Adrenocortical response of calves to transport stress as measured by salivary cortisol. Can. J. Anim. Sci. 66:637-641. https://doi.org/10.4141/cjas86-070.

Fell, L. R., and D. A. Shutt. 1986b. Use of salivary cortisol as an indicator of stress due to management practices in sheep and calves. Proceedings of the Australian Society of Animal Production 16th Biennial Conference, Canberra, Australian Capital Territory.

Fisher, A. D., B. H. Stevens, M. J. Conley, E. C. Jongman, M. C. Lauber, S. J. Hides, G. A. Anderson, D. M. Duganzich, and P. D. Mansell. 2014. The effects of direct and indirect road transport consignment in combination with feed withdrawal in young dairy calves. J. Dairy Res. 81:297-303. https://doi.org/10.1017/ S0022029914000193.

Gargon, E., S. L. Gorst, and P. R. Williamson. 2019. Choosing important health outcomes for comparative effectiveness research: 5th annual update to a systematic review of core outcome sets for research. PLoS One 14:e225980. https://doi.org/10.1371/journal pone.0225980.

Gebresenbet, G., I. Wikner, E. Y. H. Bobobee, G. Maria Levrino, and M. Villarroel. 2012. Effect of transport time and handling on physiological responses of cattle. J. Agric. Sci. Technol. A 2:800.

Goetz, H. M., D. F. Kelton, J. H. C. Costa, C. B. Winder, and D. L. Renaud. 2021. Identification of biomarkers measured upon arrival associated with morbidity, mortality, and average daily gain in grain-fed veal calves. J. Dairy Sci. 104:874-885. https://doi.org/10 $.3168 /$ jds.2020-18729.

Government of Canada. 2020. Health of Animals Regulations. Government of Canada, ed. Minister of Justice.

Grigor, P. N., M. S. Cockram, W. B. Steele, C. J. Le Sueur, R. E. Forsyth, J. A. Guthrie, A. K. Johnson, V. Sandilands, H. W. Reid, C. Sinclair, and H. K. Brown. 2001. Effects of space allowance during transport and duration of mid-journey lairage period on the physiological, behavioural and immunological responses of young calves during and after transport. Anim. Sci. 73:341-360. https:// doi.org/10.1017/S135772980005832X.

Grønstøl, H., A. D. Osborne, and S. Pethiyagoda. 1974a. Experimental Salmonella infection in calves. 1. The effect of stress factors on the carrier state. J. Hyg. (Lond.) 72:155-162. https://doi.org/10.1017/ S0022172400023342.

Grønstøl, H., A. D. Osborne, and S. Pethiyagoda. 1974b. Experimental Salmonella infection in calves. 2. Virulence and the spread of infection. J. Hyg. (Lond.) 72:163-168. https://doi.org/10.1017/ S0022172400023354.

Jacobson, L. H., and C. J. Cook. 1998. Partitioning psychological and physical sources of transport related stress in young cattle. Vet. J. 155:205-208. https://doi.org/10.1016/S1090-0233(98)80021-X.

Jongman, E. C., and K. L. Butler. 2014. The effect of age, stocking density and flooring during transport on welfare of young dairy calves in Australia. Animals (Basel) 4:184-199. https://doi.org/ 10.3390/ani4020184.

Kelley, K. W., C. A. Osborne, J. F. Evermann, S. M. Parish, and D. J. Hinrichs. 1981. Whole blood leukocyte vs. separated mononuclear cell blastogenesis in calves: Time-dependent changes after shipping. Can. J. Comp. Med. 45:249-258.

Kent, J. E., and R. Ewbank. 1986. The effect of road transportation on the blood constituents and behaviour of calves. II. One to three weeks old. Br. Vet. J. 142:131-140. https://doi.org/10.1016/0007 -1935(86)90088-6.

Knowles, T. G., S. N. Brown, J. E. Edwards, A. J. Phillips, and P. D. Warriss. 1999. Effect on young calves of a one-hour feeding stop during a 19-hour road journey. Vet. Rec. 144:687-692. https://doi .org/10.1136/vr.144.25.687.

Knowles, T. G., J. E. Edwards, K. J. Bazeley, S. N. Brown, A. Butterworth, and P. D. Warriss. 2000. Changes in the blood biochemical and haematological profile of neonatal calves with age. Vet. Rec. 147:593-598. https://doi.org/10.1136/vr.147.21.593.

Knowles, T. G., P. D. Warriss, S. N. Brown, J. E. Edwards, P. E. Watkins, and A. J. Phillips. 1997. Effects on calves less than one month old of feeding or not feeding them during road transport of up to 24 hours. Vet. Rec. 140:116-124. https://doi.org/10.1136/ vr.140.5.116.

Lensink, B. J., S. Raussi, X. Boivin, M. Pyykkönen, and I. Veissier. 2001. Reactions of calves to handling depend on housing condition and previous experience with humans. Appl. Anim. Behav. Sci. 70:187-199. https://doi.org/10.1016/S0168-1591(00)00152-0.

Levac, D., H. Colquhoun, and K. K. O'Brien. 2010. Scoping studies: Advancing the methodology. Implement. Sci. 5:69. https://doi .org/10.1186/1748-5908-5-69.

Liberati, A., D. G. Altman, J. Tetzlaff, C. Mulrow, P. C. Gøtzsche, J. P. A. Ioannidis, M. Clarke, P. J. Devereaux, J. Kleijnen, and D. Moher. 2009. The PRISMA statement for reporting systematic reviews and meta-analyses of studies that evaluate health care interventions: Explanation and elaboration. PLoS Med. 6:e1000100. https://doi.org/10.1371/journal.pmed.1000100.

Lomborg, S. R., L. R. Nielsen, P. M. H. Heegaard, and S. Jacobsen. 2008. Acute phase proteins in cattle after exposure to complex stress. Vet. Res. Commun. 32:575-582. https://doi.org/10.1007/ s11259-008-9057-7.

Lowe, G. L., M. A. Sutherland, J. R. Waas, A. L. Schaefer, N. R. Cox, and M. Stewart. 2019. Physiological and behavioral responses as indicators for early disease detection in dairy calves. J. Dairy Sci. 102:5389-5402. https://doi.org/10.3168/jds.2018-15701.

Manteuffel, G. 2002. Central nervous regulation of the hypothalamicpituitary-adrenal axis and its impact on fertility, immunity, metabolism and animal welfare - A review. Arch. Tierzucht 45:575-595. https://doi.org/10.5194/aab-45-575-2002.

Marcato, F., H. van den Brand, B. Kemp, B. Engel, M. WolthuisFillerup, and K. van Reenan. 2020. Effects of pretransport diet, transport duration, and type of vehicle on physiological status of young veal calves. J. Dairy Sci. 103:3505-3520. https://doi.org/10 .3168/jds.2019-17445.

Martig, J., P. H. Boss, J. Nicolet, and F. Steck. 1976. Etiology and predisposing factors in respiratory disease of milk-fattened veal calves. Livest. Prod. Sci. 3:285-294. https://doi.org/10.1016/0301 -6226(76)90021-X.

Masmeijer, C., B. Devriendt, T. Rogge, K. van Leenan, L. De Cremer, B. Van Ranst, P. Deprez, E. Cox, and B. Pardon. 2019. Randomized field trial on the effects of body weight and short transport on stress and immune variables in 2- to 4-week-old dairy calves. J. Vet. Intern. Med. 33:1514-1529. https://doi.org/10.1111/jvim .15482

McCausland, I. P., D. F. Austin, and R. Dougherty. 1977. Stifle bruising in bobby calves. N. Z. Vet. J. 25:71-72. https://doi.org/10 $.1080 / 00480169.1977 .34362$

McLean, K. J. E. 1984. Ultimate $\mathrm{pH}$ of veal and beef: effect of distance travelled and rest prior to slaughter. J. S. Afr. Vet. Assoc. $55: 19-22$.

Moher, D., A. Liberati, J. Tetzlaff, D. G. Altman, and PRISMA Group. 2009. Preferred reporting items for systematic reviews and meta-analyses: The PRISMA statement. PLoS Med. 6:e1000097. https://doi.org/10.1371/journal.pmed.1000097.

Mohri, M., K. Sharifi, and S. Eidi. 2007. Hematology and serum biochemistry of Holstein dairy calves: Age related changes and comparison with blood composition in adults. Res. Vet. Sci. 83:30-39. https://doi.org/10.1016/j.rvsc.2006.10.017.

Mormède, P., S. Andanson, B. Aupérin, B. Beerda, D. Guémené, J. Malmkvist, X. Manteca, G. Manteuffel, P. Prunet, C. G. van Reenen, S. Richard, and I. Veissier. 2007. Exploration of the hypothalamic-pituitary-adrenal function as a tool to evaluate animal welfare. Physiol. Behav. 92:317-339. https://doi.org/10.1016/j .physbeh.2006.12.003.

Mormède, P., J. Soissons, R. Bluthe, J. Raoult, and G. Legarff. 1982. Effect of transportation on blood serum composition, disease incidence and production traits in young calves. Ann. Rech. Vet. 13:369-384.

NAHMS (National Animal Health Monitoring System). 2014. Dairy Cattle Management Practices in the United States, 2014. USDA.

New Zealand Government. 2018. Animal Welfare (Care and Procedures) Regulations 2018. Ministry for Primary Industries. http: 
//www.legislation.govt.nz/regulation/public/2018/0050/latest/ whole.html.

Nielsen, B. L., L. Dybkjær, and M. S. Herskin. 2011. Road transport of farm animals: Effects of journey duration on animal welfare. Animal 5:415-427. https://doi.org/10.1017/S1751731110001989.

Pempek, J., D. Trearchis, M. Masterson, G. Habing, and K. Proudfoot. 2017. Veal calf health on the day of arrival at growers in Ohio. J. Anim. Sci. 95:3863-3872. https://doi.org/10.2527/jas.2017.1642.

Pogoda-Sewerniak, K., W. Janeczek, J. Kuryszko, R. Kupczynski, and M. Korczynski. 2005. The influence of diazepam on the number and morphological changes of chosen cells and tissues of organs in transported calves. International Congress in Animal Hygiene, Warsaw, Poland.

Pregel, P., E. Bollo, F. T. Cannizzo, B. Biolatti, E. Contato, and P. G. Biolatti. 2005. Antioxidant capacity as a reliable marker of stress in dairy calves transported by road. Vet. Rec. 156:53-54. https:// doi.org/10.1136/vr.156.2.53.

Roadknight, N., P. Mansell, E. Jongman, N. Courtman, and A. Fisher. 2021. Invited review: The welfare of young calves transported by road. J. Dairy Sci. 104:6343-6357. https://doi.org/10.3168/jds 2020-19346.

Sartorelli, P., S. Dominoni, and F. Agnes. 1992. Influence of duration of simulated transport on plasma stress markers in the calf Zentralbl Veterinarmed A. 39:401-403. https://doi.org/10.1111/j 1439-0442.1992.tb00198.x.

Schnyder, P., L. Schönecker, G. Schüpbach-Regula, and M. Meylan. 2019. Effects of management practices, animal transport and barn climate on animal health and antimicrobial use in Swiss veal calf operations. Prev. Vet. Med. 167:146-157. https://doi.org/10.1016/ j.prevetmed.2019.03.007.

Schrama, J. W., A. Arieli, H. Brandsma, P. Luiting, and M. Verstegen. 1993. Thermal requirements of young calves during standing and lying. J. Anim. Sci. 71:3285-3292. https://doi.org/10.2527/1993 $71123285 x$

Schrama, J. W., M. J. W. Heetkamp, M. W. A. Verstegen, W. G. P. Schouten, F. van der Veen, and F. A. Helmond. 1996. Responses of young calves on two levels of feeding, to transportation. Anim. Sci. 63:79-89. https://doi.org/10.1017/S1357729800028319.

Schrama, J. W., W. van der Hel, A. Arieli, and M. W. A. Verstegen. 1992. Alteration of energy metabolism of calves fed below maintenance during 6 to 14 days of age. J. Anim. Sci. 70:2527-2532. https://doi.org/10.2527/1992.7082527x.

Scott, K., D. F. Kelton, T. F. Duffield, and D. L. Renaud. 2019. Risk factors identified on arrival associated with morbidity and mortality at a grain-fed veal facility: A prospective, single-cohort study. J. Dairy Sci. 102:9224-9235. https://doi.org/10.3168/jds.2019-16829.

Staples, G. E., and C. N. Haugse. 1974. Losses in young calves after transportation. Br. Vet. J. 130:374-379. https://doi.org/10.1016/ S0007-1935(17)35841-4.

Stephens, D. B., and J. N. Toner. 1975. Husbandry influences on some physiological parameters of emotional responses in calves. Appl. Anim. Ethol. 1:233-243. https://doi.org/10.1016/0304 -3762(75)90016-4.

Studds, M. J., L. L. Deikun, D. E. Sorter, J. A. Pempek, and K. L. Proudfoot. 2018. Short communication: The effect of diarrhea and navel inflammation on the lying behavior of veal calves. J. Dairy Sci. 101:11251-11255. https://doi.org/10.3168/jds.2018-15003.

Tarrant, P. V. 1990. Transportation of cattle by road. Appl. Anim. Behav. Sci. 28:153-170. https://doi.org/10.1016/0168-1591(90)90051 -E.

Thomas, G. W., and P. Jordaan. 2013. Pre-slaughter mortality and post-slaughter wastage in bobby veal calves at a slaughter premises in New Zealand. N. Z. Vet. J. 61:127-132. https://doi.org/10 $.1080 / 00480169.2012 .734374$.

Toaff-Rosenstein, R. L., L. J. Gershwin, A. J. Zanella, and C. B. Tucker. 2016. The sickness response in steers with induced bovine respiratory disease before and after treatment with a non-steroidal anti-inflammatory drug. Appl. Anim. Behav. Sci. 181:49-62. https: //doi.org/10.1016/j.applanim.2016.05.016.

Todd, S. E., D. J. Mellor, K. J. Stafford, N. G. Gregory, R. A. Bruce, and R. N. Ward. 2000a. Short-term physiological effects of refeeding 5 to 10-day-old calves after fasting and transport. Proc. N. Z. Soc. Anim. Prod. 60:230-233.

Todd, S. E., D. J. Mellor, K. J. Stafford, N. G. Gregory, R. A. Bruce, and R. N. Ward. 2000b. Effects of food withdrawal and transport on 5- to 10-day-old calves. Res. Vet. Sci. 68:125-134. https://doi .org/10.1053/rvsc.1999.0345.

Trénel, P., M. B. Jensen, E. L. Decker, and F. Skjøth. 2009. Technical note: Quantifying and characterizing behavior in dairy calves using the IceTag automatic recording device. J. Dairy Sci. 92:3397-3401. https://doi.org/10.3168/jds.2009-2040.

Tricco, A. C., E. Lillie, W. Zarin, K. K. O'Brien, H. Colquhoun, D. Levac, D. Moher, M. D. J. Peters, T. Horsley, L. Weeks, S. Hempel, E. A. Akl, C. Chang, J. McGowan, L. Stewart, L. Hartling, A. Aldcroft, M. G. Wilson, C. Garritty, S. Lewin, C. M. Godfrey, M. T. Macdonald, E. V. Langlois, K. Soares-Weiser, J. Moriarty, T. Clifford, Ö. Tunçalp, and S. E. Straus. 2018. PRISMA extension for scoping reviews (PRISMA-ScR): Checklist and explanation. Ann. Intern. Med. 169:467-473. https://doi.org/10.7326/M18-0850.

Trunkfield, H. R., and D. M. Broom. 1990. The welfare of calves during handling and transport. Appl. Anim. Behav. Sci. 28:135-152. https://doi.org/10.1016/0168-1591(90)90050-N.

Uetake, K., T. Ishiwata, Y. Eguchi, and T. Tanaka. 2008. Compliance rate of livestock vehicles with welfare standards, and behavior of feeder cattle at loading ramp. Anim. Sci. J. 79:401-406. https:// doi.org/10.1111/j.1740-0929.2008.00543.x.

Uetake, K., T. Ishiwata, T. Tanaka, and S. Sato. 2009. Physiological responses of young cross-bred calves immediately after long-haul road transportation and after one week of habituation. Anim. Sci. J. 80:705-708. https://doi.org/10.1111/j.1740-0929.2009.00693.x.

Uetake, K., T. Tanaka, and S. Sato. 2011. Effects of haul distance and stocking density on young suckling calves transported in Japan. Anim. Sci. J. 82:587-590. https://doi.org/10.1111/j.1740-0929 .2010.00866.x.

United States Government. 2011. Title 49-Section 80502-Transportation of Animals. Pages 1219-1220. Government Printing Office. Accessed Nov. 10, 2021. https://www.govinfo.gov/content/ pkg/USCODE-2011-title49/pdf/USCODE-2011-title49-subtitleX -chap805-sec80502.pdf.

Warriss, P. D. 1990. The handling of cattle pre-slaughter and its effects on carcass meat quality. Appl. Anim. Behav. Sci. 28:171-186. https://doi.org/10.1016/0168-1591(90)90052-F.

Winder, C. B., K. J. Churchill, J. M. Sargeant, S. J. LeBlanc, A. M. O'Connor, and D. L. Renaud. 2019. Invited review: Completeness of reporting of experiments: REFLECTing on a year of animal trials in the Journal of Dairy Science. J. Dairy Sci. 102:4759-4771. https://doi.org/10.3168/jds.2018-15797.

\section{ORCIDS}

H. M. Goetz ㄴ https://orcid.org/0000-0001-9838-2921

C. B. Winder $\odot$ https://orcid.org/0000-0002-7314-3657

J. H. C. Costa @ https://orcid.org/0000-0001-9311-4741

T. Uyama (ํ) https://orcid.org/0000-0002-2252-3043

D. F. Kelton @ https://orcid.org/0000-0001-9606-7602

J. Dunn (ㄴ) https://orcid.org/0000-0001-7286-691X

D. L. Renaud ๑ https://orcid.org/0000-0002-3439-3987 